\title{
MASTER
}

\section{COORDINATION AND MANAGEMENT TASKS FOR \\ THE IEA SOLAR HEATING AND COOLING PROGRAM AND CCMS SOLAR ENERGY PILOT STUDY}

CONTRACT NO, DE-ACO2-79CS30108,A002

FINAL REPORT

\author{
SUBMITTED TO THE \\ U,S, DEPARTMENT OF ENERGY \\ CONSERVATION AND SOLAR ENERGY \\ OFFICE OF SOLAR APPLICATIONS FOR BUILDINGS
}

OCTOBER 1980

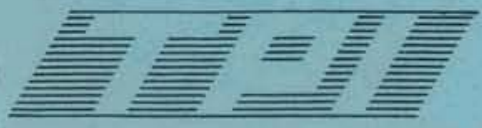

Energy, Systems, Planning and Analysis
TPI, INC.

5010 Sunnyside Avenue Beltsville, Maryland 20705

(301) $345-5200$

$345-9666$ 


\section{DISCLAIMER}

This report was prepared as an account of work sponsored by an agency of the United States Government. Neither the United States Government nor any agency Thereof, nor any of their employees, makes any warranty, express or implied, or assumes any legal liability or responsibility for the accuracy, completeness, or usefulness of any information, apparatus, product, or process disclosed, or represents that its use would not infringe privately owned rights. Reference herein to any specific commercial product, process, or service by trade name, trademark, manufacturer, or otherwise does not necessarily constitute or imply its endorsement, recommendation, or favoring by the United States Government or any agency thereof. The views and opinions of authors expressed herein do not necessarily state or reflect those of the United States Government or any agency thereof. 


\section{DISCLAIMER}

Portions of this document may be illegible in electronic image products. Images are produced from the best available original document. 
COORDINATION AND MANAGEMENT TASKS FOR

THE. IEA SOLAR HEATING AND COOLING PROGRAM AND

CCMS SOLAR ENERGY PILOT STUDY

Contract No. DE-AC02-79CS30108.A002

FINAL REPORT

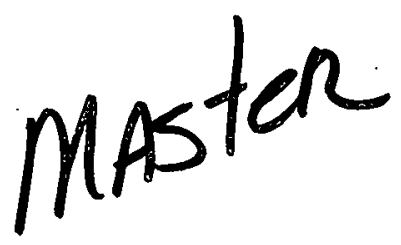

By

Sheila 8. Blum

William J. Kennish

TPI, Inc.

5010 Sunnyside Avenue

Beltsville, Maryland 20705

Submitted to the

U.S. Department of Energy

Conservation and Solar Energy

Office of Solar Applications for Buildings

October 1980 


\section{$\underline{N} \underline{0} I \underline{I} \underline{\mathrm{E}}$}

This report was prepared as an account of work sponsored by an agency of the United States Government. Neither the United States nor any agency thereof, nor any of their employees, makes any warranty, expressed or implied, or assumes any legal liability or responsibility for any third party use of the results of such use of any information, apparatus, product, or process disclosed in this report, or represents that its use by such third party would not infringe privately owned rights. 
TABLE OF CONTENTS

I. FINAL REPORT

Introduction 1

Summary of Accomplishments $\quad: \quad 7$

Conclusions $\quad 17$

II. PROJECT STATUS REPORT 23

(Covering May 15, 1980 - September 30, 1980) 


\section{ABSTRACT}

The objective of the project entitled, "Coordination/Management Tasks for the IEA Solar Heating and Cooling Program and CCMS Solar Energy pilot Study," was to provide support to DOE in connection with the aforenamed multilateral cooperative projects. The work included both management assistance for the overa11 IEA and CCMS projects and technical involvement in IEA Task I, particularly the solar system performance validation effort. The final report, covering the period March 15, 1979 - September 30, 1980, provides an overview of the accomplishments under this contract and gives conclusions and recommendations for future work. Also included in this document is the final project status report for the period May 15, 1980 to September 30, 1980 . 


\section{INTRODUCTION}

TPI, Inc. has provided management and technical support to the Department of Energy in connection with two international solar heating and cooling cooperative programs. These are the International Energy Agency (IEA) Solar Heating and Cooling Program and the NATO Committee on the Challenges of Modern Society (CCMS) Solar Energy Pilot Study. The principal individuals from TPI involved in the execution of this contract were Sheila Blum, project manager, and Dr. William Kennish, technical representative.

This support was provided to the DOE Office of Solar Applications for Buildings, which has been delegated responsibility for U.S. participation in those IEA and CCMS activities. Dr. F. Morse, Director of the Office of Solar Applications for Buildings, has served as CCMS Solar Pilot Study Director and Chairman of the IEA Solar Heating and Cooling Executive Committee. As such, the U.S. has played a major role in the leadership and management of both programs. Thus TPI has supported DOE in fulfillment of both its special leadership resonsibilities and in coordination of the U.S. technical contribution.

These two organizations constitute the major thrust of U.S. participation in multilateral and solar heating and cooling cooperative agreements. The primary objective of the collaboration is to gain information which will contribute to the development and use of solar heating and cooling technology in the United States. Cooperative programs provide a sharing of expenses and a pooling of expertise that can augment domestic R\&D efforts while secondarily promoting increased solar energy 
use abroad and improving relations with partner countries. However, because of the wide scope of projects and the variety of participants involved, there is a need for a quality managerial and technical effort to ensure proper levels of return for U.S. efforts. A brief description of the IEA and CCMS programs is provided below.

\section{IEA SOLAR HEATING AND COOLING PROGRAM}

There are twenty member countries in the International Energy Agency (IEA), which was established in 1974 under the auspices of the Organization for Economic Cooperation and Development (OECD) to strengthen international cooperation on energy policy. A cooperative agreement on solar heating and cooling was signed in 19.76; sixteen countries are participants. The original five tasks of the program have since been expanded to seven, with several others now under consideration. The trend in task development has moved. from an emphasis on component R\&D to a systems approach. The seven tasks are:

Task I -- Investigation of the Performance of Solar Heating and Cooling Systems. This task seeks to improve the capability of the participants. to assess the performance and improve the cost-effectiveness of solar heating and cooling systems.

Task II -- Coordination of Research and Development on Solar Heating and Cooling Components. The objective here is to increase the effectiveness of R\&D activities related to system components such as collectors, thermal energy storage and air conditioning units, controls, etc. 
Task III -- Performance Testing of Solar Collectors. Collector test procedures for rating thermal performance as well as reliability and durability are evaluated.

Task IV -- Development of an Insolation Handbook and Instrument Package. The aim of this task is to provide improved basic information for the design and operation of systems through better understanding, measurement and evaluation of insolation and other related weather data.

Task V -- Use of Existing Meteorological Information for Solar Energy Application. This task forcuses on improving the availability of existing meteorological data and supporting its collection and presentation for the international solar community.

Task V.I -- Performance of Solar Heating, Cooling and Hot Water Systems Using Evacuated Collectors. Participants in this recently initiated task are studying a range of evacuated collector system installations, and will report on their performance and evaluate the results.

Task VII -- Central Solar Heating Plants with Seasonal Storage. The objective is to determine the technical feasibility and cost-effectiveness of storing solar energy gained during warmer months for later use in large-scale district heating systems.

The technical support under this contract is provided for IEA Task I. The objective of Task $I$ is to improve the capbility of the participants to assess the performance and improve the cost-effectiveness of solar heating and cooling systems. To help accomplish this, common procedures are being established for: 
- Predicting system performance by computer simulation.

- Measuring and reporting thermal performance of systems

- Designing optimized systems

- Validating system simulation programs.

Furthermore, a recently initiated subtask on Solar-Assisted Low Energy Dwellings is expected to enhance the understanding of the integration of conservation and solar techniques in residential buildings.

The validation studies within Task I comprise subtask E, "Validation of Simulation Programs for Solar Heating and Cooling Systems." The validation subtask aims to increase the capabilities of participating countries to perform validation studies. A second objective of subtask $E$ is to improve each participant's overall understanding of techniques for simulating solar heating and cooling systems. The subtask $E$ work plan divides the subtask into four areas: (1) formulating methodology, (2) inventory and selection of experimental data, (3) simulating the systems and (4) reporting the comparison of predicted with reference data. Formulating the validation methodology requires the development of a common reporting format and the specification of techniques to ensure that the inputs and parameters are comparable between participants. Inventory and selection of experimental data involves examining the available reference data which can be used for comparison purposes, and selecting particular set of data for validation studies. System simulation involves each participant modeling one or more systems for which reliable experimental data is availabie, as well as identifying the assumptions used to construct the model and the sensitivity of the 
model to system parameters. Finally, each participant is required to report its results to the Operating Agent, who is required to prepare a summary report of the validation results.

CCMS SOLAR. ENERGY PILOT STUDY

Since its formation in 1969, the Committee on the Challenges of Modern Society (CCMS) has conducted numerous multilateral pilot studies as a mechanism for responding to complex technical and environmental problems facing industrialized nations. The Solar Energy Pilot Study was formed in 1973 to encourage the cost-effective and practical application of solar energy to heating and cooling of residential, commercial, industrial, agricultural and public buildings. Over 20 NATO and non-NATO countries participated, with the United States serving as pilot country and Denmark and France serving as co-pilot countries.

The major elements of the pilot study were:

- Exchange of information on national solar heating and cooling programs of participating countries.

- Development of a Systems Performance Reporting Format and exchange of reports on system performance utilizing that CCMS format.

- A working group on Solar-Assisted Low Energy Dwellings.

- A working group on passive heating and cooling (Passive Solar Applications Group). 
The Solar Energy Pilot Study was completed in 1978 and recommendations formulated by the members on transfer of certain activities to other international organizations. A two year follow-up phase was initiated at that time, during which the participants are expected to implement the recommendations and report on the progress to the CCMS. The format and Zero Energy Housing work have been transferred to the IEA. Information exchange on national programs has continued under the auspices of ISES.

The Passive Applications Group was continued under CCMS during the follow-up phase. Three working group meetings have been conducted to facilitate exchange of information between experts. Furthermore, the Passive Group has been involved in a sponsorship of two important conferences--the International Experts Group Meeting on Passive Cooling and Dehumidification, in the spring of 1980 in Miami; and an International Symposium on Passive Systems, planned for December 1980 in Nice, France. The participants will attempt to identify the most appropriate framework for continuing international cooperation in passive solar technology after 1980.

This final report presents an overview of the accomplishments under this contract (March 15, 1980 to September 30, 1980). The work consisted of coordination/management tasks for the IEA Solar Heating and Cooling Program, coordination/management tasks for the CCMS Solar Energy Pilot Study follow-up, and technical tasks for IEA Task I; particularly the validation activity. Conclusions and recommendations for future work are also included. Details of the work performed are provided in the individual project status reports. 
SUMMARY OF ACCOMPLISHMENTS

\section{A. MANAGEMENT SUPPORT \\ - Support for CCMS Follow-Up Activities}

When the CCMS Solar Energy Pilot Study was completed at the end of 1978, recommendations were formulated by the members on the action that should be taken on the various pilot study projects during a 2-year follow-up period. The recommendations concerned (1) the Zero Energy House Group, (2) the CCMS system performance reportiong format, (3) the exchange of information on national programs, and (4) the Passive Solar Applications Group. TPI was instrumental in assisting the DOE Office of Solar Applications in its lead role for implementation of the follow-up recommendations. The actions taken are described below (with the exception of the Passive Solar Applications. Group which is covered in the next section).

Ms. Blum organized two sessions at the 1979 International Solar Energy -Society (ISES) Congress in At].anta devoted to National Solar Heating and Cooling Programs, in fulfillment of the pilot study recommendation that exchange of information on that subject be continued through the ISES forum. The presentations of seventeen countries were compiled and edited by TPI and distributed to a national and international distribution list.

TPI proposed the preparation of a final report of the Zero Energy House Group and provided advice on its preparation by a Danish expert and a U.S. architectural firm. The report, "Solar Assisted Low 
Low Energy Dwellings," was distributed widely to the solar and conservation communities. The actual collaborative work of the Zero Energy House Group was transferred to the IEA Solar Heating and Cooling Program, as a Solar Assisted Low Energy Dwelling subtask under Task I. This necessitated coordinating the preparation of the annex describing the new work and participation in the editing of that annex.

As a co-author, Bill Kennish played a major role in formulation of the IEA document that superceded the CCMS reporting format. The "IEA Reporting Format for Thermal Performance of Solar Heating and Cooling Systems in Buildings," was a much-revised and expanded version of the earlier format. TPI also met with key DOE and contractor personnel to explain the format and its objectives and worked with Vitro Labs in connection with utilization of the format for two test cases in the Data Network Program.

Each completed pilot study is required to submit two annual follow-up reports on the progress made in implementing the recommendations of the study participants. "TPI prepared for DOE the First Follow-UP Report of the Solar Energy Pilot Study.

The contractor responsibilities also necessitated, at DOE instruction, interaction with U.S. CCMS officials at EPA and CCMS personnel at NATO Headquarters. They were kept informed of the status of the follow-up work and problems and concerns were discussed. 
- Support for CCMS Passive Solar Applications Group

While the other pilot study activities began a follow-up period in October 1978, the Passive Solar Applications Group continued on an active basis under CCMS due to the later start of this project.

Assistance was provided in the distribution to other members of a number of U.S. passive reports. TPI personnel participated in several CCMS passive meetings: Ms. Blum attended the CCMS Passive Applications Group working meeting in Israel in October 1979 and Dr. Kennish participated in the International Passive Cooling Experts Workshop held in April 1980 in Miami. Ms. Blum also helped to publicize the upcoming December 1980 CCMS Passive Symposium in Nice. There has also been involvement in the search for a new institutional sponsor for the CCMS Passive work.

\section{- Support for IEA Executive Committee}

Because the U.S. representative to the Executive Committee of the IEA Solar Heating and Cooling Program served as Chairman of that Committee, "the U.S. carried a major responsibility for the management of the overall program. Thus, extensive assistance was provided by TPI to help DOE in connection with its lead role.

One important aspect of this work was support for the semiannual Executive Committee meetings. This encompassed assistance in drafting of the agenda; working with the host country in connection with meeting plans; checking that action items from the previous meeting had been completed; and preparation of a careful, detailed summary of the meetings for distribution to the Committee members and a small U.S. mailing list. This was done for three Executive Committee meetings. 
Between meetings, TPI carried out additional tasks: For example, the annual progress reports of the Operating Agents for each of the seven solar heating and cooling projects were reviewed for content and English language clarity. Assistance was provided in follow-up on a wide variety of action items relating to the Executive Committee. TPI expertise was also requested in developing and/or reviewing improved management procedures for the committee, such as guidelines for preparation and approval of IEA technical reports and an assessment questionnaire. An information flyer explaining the objectives and set-up of the IEA Solar Heating and Cooling program was prepared by the Contractor. Assistance was furthermore given in keeping the Secretariat at IEA Headquarters informed on matters relating to the Solar Heating and Cooling Agreement.

- Coordination of U.S. Participation in the IEA Solar Heating and Cooling Projects

Under the direction of DOE, TPI assisted in the coordination of the U.S. participation in the seven solar heating and cooling tasks. This aspect of the contract can be subdivided into three main areas: (1) Coordination of the U.S. technical participation in the IEA projects, (2) integrating the IEA work with the U.S. solar program and (3) effecting a greater level of industry involvement.

Coordination of participation and input to the seven IEA tasks involved considerable interaction with the U.S. technical representatives (from NBS, ANL, LASL, CSU, etc.) for these projects. It required briefing them on the background of the IEA, passing on DOE 
instructions regarding their role in project meetings and U.S. concerns and objectives, learning of significant developments or concerns requiring DOE action or resolution, monitoring progress of the tasks, etc.

A more direct involvement took place in Task II when TPI requested and compiled summary sheets of over 125 DOE-funded component R\&D projects. This material was submitted to the Japanese Operating Agent as the U.S. contribution to the Task II Survey of Component R\&D projects.

Other efforts were directed toward better integration of the international projects with related domestic work. TPI organized a May 1979 meeting to review the status of the IEA tasks and to discuss coordination with the related national programs. This meeting was attended by the U.S. IE technical representatives, and representatives from DOE/IA, Office of Solar Applications for Buildings, SERI, national laboratories and SEIA. Distribution of IEA status and technical reports to a key. U.S. mailing list was one of the other steps taken to link the efforts. Ms. B.Tum presented a paper at the AS of ISES meeting in June 1980 to better inform the U.S. solar community of the IEA objectives and activities.

TPI assisted the Office of Solar Applications in coordinating reviews of new annexes to the IEA solar agreement by DOE International Affairs, the General Counsel's Office, DOE Program Managers, and outside technical experts. In general, there was considerable contact maintained over the duration of the contract with the DOE Office of International Affairs, the SERI Office of International Programs and the CS Office 
of International Programs. The Contractor regularly passed on information and reports and responded to requests for information from those offices.

TPI also supported the OSAB effort to involve the solar industry more closely in the IEA work. Two SEIA briefings were held specifically dealing with Task III (Collector Testing Performance) to determine how to maximize the benefit of that activity to industry and what role industry would play in the U.S. effort. Assistance was also provided in editing the DOE position on international development of collector standards, a sensitive issue for industry. An overview paper on the IEA solar program was presented by MS. Blum at the December 1979 SEIA Conference, along with papers by the U.S. technical experts for Tasks III, VI and VII.

\section{- International Strategy Framework}

In collaboration with Delphi Research Associated and Institute of Public Administration, TPI prepared a draft report, "Recommendations for an International Solar Policy and Strategy Framework." This report provided recommendations for a conceptual framework for DOE's international solar program. It proposed four. main international program goals and a mechanism for determining priorities and relative emphasis among solar technologies, countries, and possible projects. The intention was to provide input to the Office of International Affairs for development of strategy for an integrated international solar program. A revised version of this document was prepared under a different contract. 
B. TECHNICAL SUPPORT

- Development of Validation Methodology and Format

The contractor prepared a work plan for IEA Task I Subtask e (Validation) in cooperation with the Task I Operating Agent. TPI presented this plan at the May 1979 IEA Task I meeting in Tokyo. This plan was discussed and accepted by the Task I group. In addition, Bill Kennish gave a brief presentation on the validation methodology developed by TPI and SAI under a previous DOE contract. This presentation was well received and Dr. Kennish was asked to prepare a validation format document specific to the NBS Domestic Hot Water Validation Study. This document, "Validation Format for the Comparison of Hourly Simulation and Experimental Data," TPI/SR 79-12R, was completed in September, 1979. Based on comments received from participants in the NBS Validation Study, this document was to be revised into a general format for IEA validation studies. However, by the end of September 1980, no comments had been received from the users of the NBS Study Format, and the participants had not completed their-NBS validation studies. Therefore it appeared premature to prepare a general format.

- Validation Study of the NBS Domestic Hot Water Systems

The contractor examined sources of performance data and selected the data from NBS Domestic Hot Water experiments. Due to the format of the NBS data tapes, it was necessary to recreate the tape with a new format. NBS made the required changes under the direction of TPI. In order to identify weaknesses in the validation format and deficiencies in the data, TPI undertook a validation study using the 
NBS tape and the draft validation format. This effort revealed three serious problems with the dat. These problems and proposed solutions were documented and sent to the Operating Agent, Ove Jorgensen (see "Format Implementation" attachment to TSR-IEA-79-4). TPI provided additional data to Mr. Jorgensen in response to requests by other Task I participants for specific additional information.

During November and December 1979, TPI formulated TRNSYS models to simulate each of the four systems selected from the NBS data. Using weather data from the NBS tape as input to the TRNSYS models, simulation results were obtained for all four systems. These results were to be presented at the February 1980 IEA Task I meeting in Lausanne, Switzerland. However, when TPI results were compared to the LASL results, considerable differences were discovered between the measured energy collected. This inconsistency prevent TPI from completing a formal document for distribution at the Lausanne meeting. At the Lausanne meeting, Jim Hedstrom of LASL mentioned that the LASL data had been modified to account for a data problem. These modifications were incorporated into the TPI study, and the results were released in a document entitled, "IEA Validation Study Using NBS Domestic Hot Water Systems," TPI/SR 80-05, dated May 12, 1980.

Participants in the IEA Task I meeting in Lausanne proposed a sensitivity analysis for the NBS simulation (see the March 15 trip report by William Kennish, TPI, on the Lausanne meeting). T.PI completed this sensitivity analys is in early 0ctober and presented it under the title "Sensitivity Studies of the NBS Sing Tank, Indirect Domestic Hot Water System," TPI/SR 80-12. Copies of this report were distributed at the 
October 1980 IEA Task I meeting in San Francisco. The study presents the results of nine TRNSYS simulations. These simulations consist of variations to the TRNSYS model for the single tank indirect DHW system discussed in the "IEA Validation Study Using NBS Domestic Hot Water Systems," TPI/SR 80-05.

\section{- Additional Technical Support for IEA Task I}

Prior to the initiation of this contract in March 1979, TPI was involved in the drafting of a reporting format for the IEA. As a result of this earlier involvement and familiarity with the format document, TPI was asked to maintain a small level of involvement in the finalization and implementation of the format within the U.S. A. Dr. Morse's request, TPI organized a meeting with DOE, Vitro, NBS, and TPI personnel where the use of the format was discussed. It was decided that Vitro would attempt to use the reporting format for two sites and document any problems encountered. TPI has provided assistance to Vitro when necessary and has continued to pursue other avenues for utilizing the format within the U.S. TPI has distributed approximately 70 copies of the document to key U.S. solar energy professionals. A list of the recipients of the report is provided in Attachment 1 .

At the time of this writing Vitro was internally reviewing the second draft of the two reports and no feedback had been provided. Jim Hedstrom of LASL has prepared a report of the LASL Study Center according to the format and distributed it to Task I members for review and comment. He will attempt to document the difficulties encountered as soon as possible. 
The contractor revised the optimization subtask description and work statement in cooperation with the Task I Operating Agent. This revision was presented at the May 1979 Task I meeting in Tokyo. TPI has also provided to the Operating Agent extensive comments on the restructuring and rewriting of the Optimization Report. 
ATTACHMENT 1

DISTRIBUTION FOR REPORTING FORMAT

J. Dollard, DOE

C. Gates, DOE

F. Glaski, DOE

H. J. Hale, DOE

R. Hassett, DOE

L. Herwig, DOE

R. Jordan, DOE

W. Kaspar, DOE

T. Kurkowski, DOE

J. Leech, DOE

W. Lemeshewsky, DOE

M. Maybaum, DOE

T. Mock, DOE

$F$. Morse, DOE

S. Sargent, DOE

S. Schweitzer, DOE

M. Soliman, DOE

J. Vanderryn, DOE

J. Zimmerman, DOE

F. Arnold, SERI

C. Berberich, SERI

C. Bishop, SERI

K. Collier, SERI

M. Goldberg, SERI

L. Groome, SERI

M. Holtz, SERI

C. Leboeuf, SERI

F. Kreith, SERI

A. Heitz, LBL

S. Schiller, LBL

M. Wahl ig, LBL

M. Warren, LBL

W. Brooksbank, MSFC

C. Messer, MSFC

M. Myers, MSFC

W. Richardson, MSFC

S. Kapoor, Argonne

A. Michaels, Argonne

J. Peerson, Argonne

D. Balcomb, LASL

C. Bankston, LASL

J. Hedstrom, LASL

E. Streed, NBS

J. Hill, NBS

W. Freeborn, HUD

D. Moore, HUD
J. Andrews, Brookhaven

D. Livingston, EPA

F. Wessling, TVA

T. Freeman, Altas

P. R. Rittelmann, Burt, Hill et al.

L. Hall, Carrier Corp.

G. Lof, CSU

G. Purcell, EPRI

D. Hoel, Exxon

B. Mead, Grumman

H. Curran, Hittman Assoc.

J. Carlock, Mueller Assoc.

T. King, Mueller Assoc.

J. Crane, SAI

T. Hill, SAI

J. Kelly, Vitro

E. Schatzberg, Vitro

R. Waterman, Vitro

C. Rooks, LaCrosse, WI

G. Tenet, SEIA

S. Karaki, CSU

N. Lior, U. PA

J. Duffie, U. WI 
CONCLUSIONS

\section{A. GENERAL}

U.S. participation in the IEA Solar Heating and Cooling tasksharing cooperative projects has provided benefits to the United States solar program. For a relatively small cost, the U.S. has had access to solar technical expertise from fifteen other countries. Some of the work has effectively augmented work carried out domestically. While the U.S. contribution to the various technical work has been a major one, it has by no means been one-sided. Some of the benefits are only now becoming obvious as the first technical reports begin to be published or the projects reach stages which yield meaningful results. Certain of the new activities--low energy dwellings, evacuated collector systems, and district heating systems, for example--should prove especially beneficial. Furthermore, participation in the IEA permits the U.S. to monitor the status of the technical capability of the participating countries.

For a variety of reasons, the CCMS Passive Solar Applications Group has not been a very successful vehicle for cooperation. It is clear, however, that international cooperation in passive technology is desirable and a suitable framework must be identified. Other elements of the CCMS Solar Energy Pilot Study have left a meaningful and well-established legacy. The system performance reporting format, the Zero Energy House Group, and exchange of information on national solar heating and cooling programs were considered to be worthwhile activities and have been transferred to the IEA and ISES. Thus, many goals of the follow-up period have been successfully accomplished. 


\section{B. MANAGEMENT SUPPORT}

TPI is proud to have supported the Department of Energy in fulfilling its obligations with respect to the IEA and CCMS Solar Heating and cooling cooperative efforts. We believe that the assistance provided has contributed to the reputation gained by those programs for being wel1-managed.

As a result of the experience and contacts built up by TPI in the areas of solar heating and cooling and technical cooperation, it was able to effectively help the Department carry out the U.S. IEA and CCMS responsibilities. The status of all the projects were carefully followed and TPI served as a focal point for gathering information on progress and problems relating to those activities. TPI worked with the U.S. technical contact persons for each project to assure that the U.S. obligations were completed, and deadlines were met. Also, during the contract period, two important steps were taken. In one action, improved linkage of the international work with the relation national programs was undertaken. Secondly, attempts were made to increase the involvement of U.S. industry in the international work.

Looking to the future, additional action is recommended to increase the effectiveness of the international cooperative activities and to build on the past accomplishments. The work begun to better integrate the national and international activities should be continued. Likewise, discussion of the role of U.S. industry and exploration of ways to increase the benefit to industry of the various international activities should be 
continued. Most critical is the need for preparation of an overall management plan for the technical cooperative projects in the Office of Solar Applications for Buildings based on a coherent strategy which establish clear goals and priorities. It should clearly define various organizational roles, standardized reporting requirements, formal procedures for linkage with the domestic program and with industry, criteria for establishing new projects and guidelines for evaluation of existing ones.

\section{TECHNICAL SUPPORT}

Validation of computer simulation programs is a difficult project, whether carried out domestically or internationally. However, specific benefits have been realized from the Task I validation activities. First, the users of various programs have identified errors and/or limitations in their respective programs as a result of comparison to experimental data. This was particularly true in the case of DHW single tank direct systems. There has also been an upgrading of the data which was originally made available for the studies and can now be offered more confidently to other researchers.

With respect to the benefit realized by the U.S., several factors have resulted in a diminished impact. First, the validation studies have been curtailed after two studies using U.S. data. The third proposed study was to use European data, thereby providing us with access to data for which we did not have to pay. The second factor is that the communication of results of the validation studies has not been properly planned for or carried out. This, in fact, is part of a larger problem which is that insufficient time was spent in developing a validation plan with 
which these studies could have been carried out. This would have ensured the relevancy of each study proposed and carried out by the group. This is, in fact, a fairly common deficiency in many of the IEA activities and should be seriously reviewed for future work.

It is suggested that perhaps one of the most effective efforts this group could put forth is the development of a high quality, evaluated and documented data base for solar systems throughout the world. This data could then be used by any member for a variety of purposes. Data could be obtained at varying levels of sophistication, ranging from annual estimates of solar savings based on utility bills to detailed minute-by-minute data of the system performance. 


\section{APPENDIX 1}

PRESENTATIONS AND REPORTS PREPARED UNDER THIS CONTRACT

Sensitivity Studies of the NBS Single Tank, Indirect Domestic Hot Water System. TPI/SR 80-12, October 20, 1980.

Draft Validation Format for the Comparison of Hourly Simulation and Experimental Data. TPI/SR 79-12R, August 1980.

"International Tectinical Collaboration in the IEA Solar Heating and Cooling Program and the NATO-CCMS Solar Energy Pilot Study," S. Blum and F. Morse (DOE), presented at AS/ISES Annual Meeting, Phoenix, Arizona, June 2-6, 1980.

IEA Validation Study Using NBS Domestic Hot Water Systems, W. J. Kennish and M. Ahmed, TPI Special Report 80-05, May 12, 1980.

IEA Cooperative Programme to Develop and Test Solar Heating and Cooling Systems (IEA Flyer), S. Blum and N. Harrison, April 1980.

Recommended International Solar Energy Strategy for the U.S. Department of Energy, Sheila Blum, W. J. Kennish et al., TPI, Inc., April, 1980 .

Reporting Format for Thermal Performance of Solar Heating and Cooling Systems in Buildings, for Task I of the IEA Solar Heating and Cooling Program, P. Isakson, W. J. Kennish, and E. Ofverholm, February 1980.

Format Implementation (for the IEA Task I Subtask e Validation Study) - Attachment to TSR-IEA-79-4.

IEA Task I-Subtask e. Validation of Simulation Programs for Solar Heating and Cooling Systems: Work PTan. Attachment to TSR-IEA-1-79.

"International Technical Collaboration in Solar Heating and Cooling Research and Development," S. Blum, presented at the SEIA meeting, Honolulu, Hawaii, December 13, 1979.

First Follow-Up Report: CCMS Solar Energy Pilot Study, S. Blum, P. V. Ward, and J. Allen, TPI, Inc., October 1979.

Validation Format for the Comparison of Hourly Simulation and Experimental Data, for Task I of the IEA Solar Heating and Cooling Program, Subtask E, W. J. Kennish, TPI Special Report 79-12, September 1979.

National Solar Heating and Cooling Programs, proceedings of reports given by CCMS Solar Energy Pilot Study members at the International Solar Energy Society Congress, Atlanta, Georgia, May 28-June 1, 1979, S. Blum and J. Allen, editors, TPI, Inc., August 1979. 
APPENDIX 2

CONFERENCES AND MEETINGS ATTENDED

Sheila Blum

- Executive Committee, IEA Solar Heating and Cooling Program: May 1979, October 1979 and April 1980.

- DOE Passive Update Meeting, September 1980.

- AS of ISES, Phoenix, Arizona, June 1980.

- SEIA Pacific Meeting, December 1979.

- CCMS Passive Applications Group, October 1979.

- DOE/DOC Solar Export Issues Workshop, August 1979.

- ISES, Atlanta, Georgia, May 1979.

- Task II Meeting, Tokyo, Japan, May 1979.

William Kennish

- International Passive Cooling Workshop, Miami, Florida, Apri 1980.

- IEA Task I Meeting, Lausanne, Switzerland, February 1980.

- IEA Task II Meeting, Lausanne, Switzerland, February 1980.

- Task I Meeting, Tokyo, Japan, May 1979.

- DOE Passive Update, September 1980 
PROJECT STATUS REPORT 


\title{
PROJECT STATUS REPORT
}

\section{COORDINATION/MANAGEMENT TASKS FOR THE \\ IEA AND CCMS SOLAR HEATING AND COOLING PROGRAIS}

CONTRACt Number DE-AC02-79CS30103.A002

Period Covering May 15, 1930 - September 30, 1980

\author{
TPI, INC, \\ EnERgy; Systems \& Analysis \\ 5010 SUNNYSide AVENUE \\ Beltsville, Maryland \\ 20705
}




\section{STATUS OF TASKS}

Task 1. COORDINATION/MANAGEMENT TASKS

Subtasks 1.1, 1.2, 1.3 - Completed.

Subtask 1.4 Coordination/Management Support for the CCMS

Follow-Up Activities

- Sheila Blum, Project Manager for this contract, had several discussions with Dick Livingston at EPA, U.S. Coordinator for CCMS, concerning CCMS solar follow-up. Discussions centered around the French-hosted. Passive Conference to be held in Nice in December 1980 and the second follow-up report of the solar pilot study. NATO/CCMS headquarters decided that the second follow-up reports of al.1 the energy pilot studies would be postponed from Fall 1980 to Spring 1981.

- TPI assisted DOE in the coordination of U.S. participation in the Nice Passive Conference. U.S. experts identified by DOE and SERI were contacted to solicit submittal of abstracts. Options for funding travel of U.S. authors were also explored. A U.S. passive mailing list was also supplied to the French organizers. A flyer publicizing the Conference was prepared by TPI and distributed at the AS/ISES meeting in June 1980 in Phoenix. 
- The Project Manager attended the September 22-24 Passive Update Meeting in Washington, D.C. to learn of recent accomplishments and new directions in the passive domestic program.

- The Final Report of the CCMS Zero Energy House Group, "Solar Assisted Low-Energy Dwellings" was distributed in June 1980 to a U.S. and international mailing list.

Subtask 1.5 Coordination and Management Support for the IEA Solar Heating and Cooling Program

- Ms. Blum presented a paper at the June 1980 AS/ISES meeting in Phoenix on the status of the CCMS and IEA Cooperative Programs. A copy of the paper (coauthored by F. Morse, DOE) prepared as a handout for that session is transmitted with this report.

- The Task II report prepared by the Japanese Operating Agent on Solar Heating and Cooling Component R\&D Projects was carefully reviewed. Extensive editing was required by TPI for English Tanguage accuracy.

- A write-up prepared by the IEA Secretariat on the Solär Heating and Cooling Program intended for inclusion in the IEA's annual RD\&D report was reviewed.

- TPI prepared material on the IEA Solar Heating and Cooling Program for an August 1st briefing of Robert San Martin (DAS for Field Operations and International Programs). 
During this reporting period, the Contractor also supplied information on the status and future plans of the IEA program to DOE Office of International Affairs, SERI International Programs and the DOE/CS/FI office.

- At the request of the contract technical manager, the following information was obtained from various personnel responsible for solar heating and cooling multilateral and bilateral projects: (1) FY 81 foreign travel projections, (2) FY 81 funding requirements, and (3) FY 81 work statements.

- The review of the modification to Annex I of the Implementing Agreement was coordinated. There was some difficulty in arriving at a version acceptable to the U.S. and to the other participants.

- The Contractor coordinated the preparation of a draft proposal for a task on solar retrofit. The proposal was drafted by DOE personnel, edited by TPI, and revised by DOE. The final version was submitted to Canada which was preparing an integrated version, based on input from a number of countries.

- TPI coordinated the preparation by John Andrews of Brookhaven of a preliminary proposal for a solar-assisted ground-coupled heat pump cooperative project. This was distributed to the IEA Executive Committee-members. 
- The Contractor collected material on the U.S. domestic hot water program for transmittal to the Canadian representative who was distilling information submitted in order to identify fruitful areas for cooperation.

- A letter from F. Morse proposing a particular approach to collaboration with developing countries within the IEA RD\&D projects was circulated to the Executive Committee. A draft letter on this subject to the Secretariat was circulated to DOE/IA and DOE/CS/FI for concurrence.

- Ms. Blum participated in a September 18 briefing of DOE active solar systems development staff on IEA Task III. Presentations were made by F. Morse, E. Streed (NBS) and W. Dokos (DSET) on the collector testing work in that task and discussions held on how to integrate the international with the related domestic work. Additional meetings will be scheduled. The Contractor was also involved in the organization of a meeting to brief key industry people on the Task III activities.

- TPI provided assistance to the Chairman in connection with the planning and preparation of the Fall 1980 Executive Committee Meeting in Ottawa, Canada. Responsibilities included drafting an agenda, reviewing all action items from the previous meeting, and assuring that the Chairman had the information necessary to effectively deal with new and old business that would arise at the meeting. The 
Contractor also made group hotel and travel arrangements for those IEA Executive Committee members who wished to attend the Passive Conference in Amherst, Massachusetts.

Subtask 1.6 Coordination, Participation and Follow-Up for the IEA Executive Committee Meeting, Stresa, Italy

- Ms. Blum prepared and distributed the minutes from the Spring 1980 Executive Committee meeting in Stresa. (These minutes were included in the trip report submitted previously to the Contract Office.) Much attention was given to follow-up of action items, some of which are detailed in Section 1.5 .

Subtask 1.7 - Completed.

Subtask 1.8 - Final Project Report--Completed with submittal of this report.

Subtask 1.9 - Completed. 
Task 2. TECHNICAL SUPPORT

Technical work on the contract has continued throughout this time period although at a relatively low level. Encouragement for the U.S. implementation of the IEA Reporting Format has continued and assistance provided to Vitro when necessary. Additional effort may be required in the future with respect to the passive portion of the format. Apparently a U.S. Passive Reporting Format is being formulated by DOE/SERI for reporting the performance of passive solar systems. If this U.S. format proves effective it may be wise to attempt to incorporate its substance into the IEA Format. The IEA format was always somewhat weak in the passive area and this may be an opportunity to upgrade the IEA Reporting Format and to bring the U.S. and IEA solar programs back together.

The initial validation runs were completed, documented and submitted to Dr. Jorgensen of the IEA. In September the specifications for the sensitivities studies were received. The simulations have been performed and were documented for presentation at the Task I San Francisco meeting in late October. The results are contained in, "Sensitivity Studies of the NBS Single Tank Indirect Domestic Hot Water System," TPI/SR 80-12 which is transmitted with this report.

Because of the Solar. Assisted Low Energy Dwelling Validation work being discussed, there has also been an attempt made to more closely interact with the domestic passive program. This interaction has uncovered a validation activity within the passive program to identify a validation methodology and sources of data. Detailed information on this program has been requested and will be evaluated for potential use in the SALED validation activities. 
The general validation format has not been prepared from the NBS format. The NBS study has not yet been completed and no comments from other participants regarding a general format have been received, thereby making it appear somewhat premature to propose a general format. It appears that we are realizing, however, that if a general format is prepared, it will have to be very nonspecific and simply lend guidance to each study. The worth of such a document can be a topic of discussion at the San Francisco meeting. 